\title{
Sajtóirányítás és háborús propaganda az I. világháború időszakában
}

\author{
Media Management and War Propaganda during the World War I
}

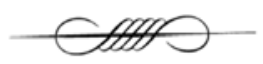

\begin{abstract}
In the 1910-s, press flourished in Hungary. However, as a result of the political crisis preceding the World War, then the outburst of the war, there were significant restrictions introduced in the field of the press, while after the start of the fights, compulsory censorship was introduced. The Military Supervisory Commission was taking over the control of mass communication to an ever increasing extent. Publishing papers infringing military interests with their news were suspended for shorter or longer periods. The newly set up Press Command Post fulfilled the tasks of publishing military information and supervising war coverage. This organisation not only provided newscasts, but also monitored the international press and involved the representatives of the most varied art forms (writers, painters, even film producers) in the war propaganda. In the heartland, interest towards military events and at the front, towards home conditions increased more and more, however, the information flow was considerably restricted both here and there. Due to the prolongation of the war, and the increase in difficulties and losses, the role of the propaganda activity performed among the soldiers and within the heartland became more and more important. Many people considered that all-in propaganda, also received a decisive role in the all-in war.
\end{abstract}

\section{KEYWORDS}

World War I, media management, mass communication, war propaganda

DOI 10.14232/belv.2019.2.6 https://doi.org/10.14232/belv.2019.2.6

Cikkre való hivatkozás / How to cite this article: Olasz Lajos (2019): Sajtóirányítás és háborús propaganda az I. világháború időszakában. Belvedere Meridionale 31. évf. 2. sz. 104-122. pp. 
(Creative Commons) Nevezd meg! - Így add tovább! 4.0 (CC BY-SA 4.0)

(Creative Commons) Attribution-ShareAlike 4.0 International (CC BY-SA 4.0)

www.belvedere-meridionale.hu

\section{HÁBORÚS MÉDIA: SAJTÓIRÁNYÍTÁS ÉS TÖMEGTÁJÉKOZTATÁS}

A sajtó a 20. század elején a fénykorát élte. A szépirodalomról leváló publicisztika egyre fontosabb szereplőjévé vált a közéleti kérdések megvitatásának. Kialakult a professzionális újságírás, tőkeerős kiadók jelentek meg, jelentősen fejlődött a nyomdatechnika. Így a lapok modern tömegtermékekké válták. Bővült az írni-olvasni tudók száma, és ezzel szélesedett az újságolvasó közönség. Az 1910-es évekre a „hírfogyasztás” fokozatosan beépült a mindennapi tevékenységek közé. A háború kirobbanását követően gyorsan nőtt a hírek utáni érdeklődés, ugyanakkor nagyobb igény merült fel, hogy a média egyfajta kikapcsolódást is biztosítson az embereknek. Mindez a sajtópiac további bővüléséhez vezetett. A világháború időszakában a legnagyobb országos lapok (Kis Újság, Friss Újság) 150-200 000 példányban, más fővárosi újságok (Pesti Hirrlap, Az Újság, Magyarország) 50-60000 példányban jelentek meg. ${ }^{1}$

Az első világháborút nem a tömegek nacionalista lelkesedése váltotta ki. Spontán háborúpárti megnyilvánulásokra, társadalmi megmozdulásokra a kölcsönös hadüzeneteket megelőző időszakban csak elvétve került sor. A háború ténye teremtett olyan közhangulatot, amely a felfokozódó nemzeti érzés jegyében elfogadta és támogatta a konfliktus fegyveres megoldását. Ennek a hangulatnak a felszításában és fenntartásában jelentős szerepet játszott a média, a sajtópropaganda. ${ }^{2} \mathrm{Az}$ emberek többségét nem a fegyveres harc hősi romantikája vagy az ellenség gyülölete mozgatta, hanem a háborút a másik fél agressziójának tekintve, a haza, az igazság védelme mellett kötelezték el maguk. A nemzeti összetartozás érzésén és a közös értékek védelmén túl voltak, akiket a háború előidézte változások reménye is motivált. Sokan, főként polgári, értelmiségi körökben (Thomas Mann, Rainer Maria Rilke, Hugo von Hofmannsthal) azt várták, hogy a háborús krízis felbontja a régi, megkövesedett társadalmi és gondolkodásbeli struktúrákat, és a győzelmet hozó közös erőfeszítés nyomán egy nyitottabb, modernebb korszak kezdődik, új társadalmi szabályokkal és értékpreferenciákkal. ${ }^{3}$

A háborús hangulat Magyarországon is elsősorban a városi polgári rétegek, a középosztály, az értelmiség körében jelentkezett. A társadalmi véleményformálás tekintetében meghatározó rétegek háború melletti kiállása azután úgy jelent meg a nyilvánosság előtt, mintha az egész lakosság álláspontja volna. Ezt az egyoldalú beállítást egyébként maga a háborús propaganda is erősítette. Az újságcikkekben, a fotókon csak magabiztos, lelkesen bevonuló emberekkel lehetett találkozni, aggodalom, kétség alig jelent meg a médiában. Holott a háborút a szellemi élet

\footnotetext{
${ }^{1}$ GoRda 2012. 47-48.; LIPTÁK 2002. 146.

${ }^{2}$ Hastings 2014. 190-191.; SCHMitT 2002. 231-233.

${ }^{3}$ VocelKa 2014. 147.; BIHARI 2014. 156-157.
} 
jelentős része is elutasította, köztük Ady Endre, Babits Mihály, Kassák Lajos. A nyár folyamán több ellenzéki lap (Népszava, Magyarország, Világ) még elkerülhetőnek nevezte a háborút, majd a hadiállapot beállta után látványos kardcsörtetés nélkül a kötelességteljesítésre hívta fel a figyelmet. ${ }^{4}$ A lakosság többsége inkább beletörődve, mintsem lelkesedve fogadta a mozgósítás hírét. Az agrárnépesség körében a munkaképes férfilakosság egyharmadának bevonulása különösen komoly problémákat okozott. Megnehezítette a gazdaság müvelését, a megélhetést biztosító jövedelem megszerzését. A szervezett munkásság elutasította a háborút, illetve az azzal járó kivételes állapot bevezetését, amely alapján erősen korlátozták az állampolgári jogokat. A nemzetiségi lakosság egy része, ha burkoltan is, érezhető szimpátiát táplált Szerbia és Oroszország, illetve az őket támogató nyugati hatalmak iránt. ${ }^{5}$

A háború kirobbanása nyomán, a közvélemény alakítása, a milliós katonatömegek, illetve a polgári lakosság gondolkodásának befolyásolása terén a nyomtatott szövegek, az álló- és mozgóképek a korábbiaknál is lényegesen nagyobb szerepet kaptak. Az egyes kormányok igyekeztek minél szélesebb körű befolyást gyakorolni a sajtó müködésére, minél szorosabb irányítás alá vonni a tömegtájékoztatás intézményeit, hogy a média is a hadviselés érdekeit szolgálja. A sajtó azonban csak olyan nézeteket tudott hatásosan közvetíteni, amelyek tőle függetlenül is jelen voltak a közvéleményben, melyekre vonatkozóan bizonyos mértékű társadalmi elvárás, támogatottság jelentkezett. Nem a sajtó teremtett tehát háborús hangulatot, de az egyes társadalmak ráhangolásában, a hazafias érzések felkeltésében, az ellenséggel szembeni indulatok fokozásában vagy a könnyü győzelem hamis reményének táplálásában a tömegmédia jelentős szerepet játszott. A harcoló felek komoly erőforrásokat mozgósítottak, hogy minél hatékonyabban tudják alkalmazni ezt a „fegyvert” is. ${ }^{6}$

A nemzetközi feszültség fokozódását tapasztalva a magyar kormány igyekezett minden rendelkezésére álló eszközt a háborús felkészülés szolgálatába állítani. Lépéseket tett, hogy a sajtót is közvetlen ellenőrzése alá vonja, és ezzel a közvélemény alakulására nagyobb hatást gyakoroljon. Sajtöügyekre vonatkozóan a többször módosított 1848. évi XVIII. tc. volt érvényben. Ezt egészítette ki az 1912. évi LXIII. tc., a háború idején életbe léptethető kivételes intézkedésekről, az előzetes sajtócenzúra elrendelésének lehetőségéről és a hadviselés érdekeit sértő írásokat közlő sajtótermékek terjesztésének betiltásáról. Tisza István miniszterelnök 1914 áprilisában új sajtótörvényt fogadtatott el (1914. évi XIV. tc.) a parlamenttel, melyet nemcsak az ellenzék, hanem még a kormányhoz közel álló közéleti személyiségek egy része, köztük Rákosi Viktor is élesen kritizált. A kortársak, némi túlzással, a sajtó „államosításáról” beszéltek, mert az új szabályozás jelentősen megnövelte a kormány beavatkozási lehetőségét a médiaügyekbe. Májusban egy párizsi tömegkommunikációval foglalkozó konferencián a résztvevők mélyen lesújtó véleményt fogalmaztak meg az új magyar sajtótörvényről, melyet még az oroszországi korlátozásoknál is súlyosabbnak ítéltek. ${ }^{7}$

A szarajevói merénylet után, a hivatalos kormányreakciót ki sem várva a magyar közélet egyes csoportjai kemény fellépést, fegyveres elégtételt sürgettek. Számos lap támogatta a Szerbia „megfékezését” célzó intézkedéseket, a Belgrádnak küldött ultimátumot. A hadüzenet bejelentésekor

\footnotetext{
${ }^{4}$ Bihari 2014. 150-151; Hajdú-Pollmann 2014. 66-68.

${ }^{5}$ Romsics 2010. 121-122.

${ }^{6}$ PAÁl 2010. 143-144; Músi 1984. 192.

${ }^{7}$ M. Kondor 1975. 76.; KÓKAY-BuZINKAY-MurÁNYI 1999. 170.
} 
a sajtó prognózisok többsége gyors és sikeres hadműveletekről és a békeállapot közeli visszaállításáról szólt. Az első hetekben a kormányhoz közelálló lapok hangnemét Tisza, taktikai okokból visszafogta, így egyes ellenzéki konzervatív orgánumok gyakran élesebben fogalmaztak, és határozottabban követelték a merénylet mögött feltételezhető szerb hivatalos körökkel szembeni megtorlást, mint a kormány szócsöveinek számító újságok. A liberális, polgári radikális vagy szociáldemokrata sajtóra a törvény adta lehetőségek mellett a kormány informális úton is igyekezett nyomást gyakorolni. A szarajevói merényletet követően, de még a hadüzenet előtt a miniszterelnök magához kérette Garami Ernőt, a Népszava főszerkesztőjét, és figyelmeztette, hogy ha Szerbia ellen tervezett fellépéssel kapcsolatban a lap élesen szembehelyezkedik a kormány politikájával, akkor a kivételes hatalommal élve, be fogják tiltani a megjelenését. ${ }^{8}$

A hadüzenet bejelentését megelőző napon, 1914. július 27-én érvénybe lépett a kivételes hatalomról szóló törvény. A vele párhuzamosan kiadott végrehajtási utasítás közzétette azokat az előre kidolgozott kormányrendeleteket, melyek a sajtóra vonatkozóan is új szabályozást vezettek be. Ezek lehetőséget adtak a postaforgalom, a távíró és távbeszélő használatának kormányzati ellenőrzésére, illetve a kötelező sajtócenzúra bevezetésére. A kormány azonnali hatállyal megtiltotta a haderő állapotára, tevékenységére vonatkozó kérdéseknek a lapokban történő tárgyalását. Erre vonatkozóan csak a hadvezetés vagy a Miniszterelnökség által kiadott hivatalos tájékoztatókat adhatták közre. Átfogó érvényű előzetes sajtócenzúrát egyelőre nem vezettek be, de az igazságügyi miniszter által kiadott rendelet alapján, az ,arra okot szolgáltató” lapoknál, melyek élesebben kritizálták a kormány politikáját, ideiglenesen alkalmazták ezt a megoldást. A háború kezdetén több helyi munkáslapot, nemzetiségi újságot betiltott a kormány. Ugyanakkor a megnövekedett hírigény kielégítése, illetve a sajtónak szánt fontos közfeladat, a hazafias propaganda ellátásának biztosítása érdekében díjmentessé tették az újságok postai terjesztését, a belügyminiszter feloldotta egyes lapok (köztük a Népszava) utcai árusításának tilalmát, a honvédelmi miniszter pedig intézkedett, hogy az újságírókat lehetőleg ne harcoló csapatokhoz, hanem a haderő propaganda csoportjához hívják be. ${ }^{9}$

A sajtó irányítása, ellenőrzése három szerv hatáskörébe tartozott. A Miniszterelnökség sajtóirodája elsősorban a polgári vonatkozású híráramlást felügyelte, az Igazságügyi Minisztérium és ügyészségek a cenzúra működését biztosították, az újonnan felállított Hadi Felügyeleti Bizottság (HFB) pedig a hadviselés érdekeit érintő híradásokat ellenőrizte. A HFB a Honvédelmi Minisztérium alosztályaként müködött, de bizonyos tekintetben alárendeltje volt a közös Hadügyminisztérium Hadi Felügyeleti Hivatalának (Kriegsüberwachungsamt), illetve a közös (császári és királyi - k.u.k.) haderő Vezérkara Nyilvántartó Irodájának is. A sajtóellenőrző szervezetek kezdetben még párhuzamosan, egymástól viszonylag függetlenül működtek. A katonai vezetés azonban fontosnak ítélte, hogy a háborúval kapcsolatos minden számottevő kérdésben a tömegtájékoztatás és a propaganda közvetlen katonai irányítás alatt álljon. A HFB egyre több feladatot vett át a miniszterelnöki sajtóirodától, így 1915-re a kül- és belföldi hírszolgáltatást gyakorlatilag már ez a szerv felügyelte. ${ }^{10}$

HFB keretében 1914. július 24-én külön sajtóalbizottságot állítottak fel. Ennek munkájában 26 kormányzati delegált (a Honvédelmi, a Belügy-, a Pénzügy-, az Igazságügyi, a Földmüvelésügyi,

\footnotetext{
${ }^{8}$ Galántai 2001. 104-105.; VARga 1996. 149-150.; Gorda 2012. 76.

${ }^{9}$ Mucsi 1984. 194.; Gorda 2012. 77.

${ }^{10}$ M. Kondor 1975. 79.; Mucsi 1984. 195.
} 
a Kereskedelmi, a Horvát-Szlavón Minisztérium képviselői), valamint a közös haderő vezetése által kiküldött szakértők vettek részt. A HFB elnöki posztját a honvédelmi államtitkár látta el, a sajtóalbizottság munkáját pedig a Miniszterelnökség sajtóosztályának vezetője koordinálta. Ehhez hasonlóan, a Monarchia másik felében a Hadi Felügyeleti Hivatal keretében is külön sajtóbizottságot szerveztek. Ezek a testületek döntöttek arról, hogy milyen háborúval kapcsolatos információk közölhetők vagy kerülendők az újságokban. Az országos lapoknak, ha nem kormányzati forrásból szerezték az értesüléseiket, cikkeiket rendszerint bemutatták előzetes ellenőrzésre a HFB sajtóalbizottságának, mert annak jóváhagyásával, az utólagos számonkérés kockázata nélkül közölhették. A vidéki lapok bizalmas tájékoztatót kaptak az újonnan bevezetett cenzúra-szabályokról. Figyelmeztették a szerkesztőket, hogy alaposan gondolják át a hadviselés érdekeit akár csak közvetetten érintő helyi hírek közlését is. Körültekintően járjanak el például hazatérő katonák beszámolói esetében, és ne közöljenek konkrét katonai adatokat vagy részletes harci beszámolókat. ${ }^{11}$

A katonai vonatkozású híradások központi ellenőrzésére, a front és a hátország közötti kommunikáció, illetve a háborús propaganda irányítására a Szerbiának küldött hadüzenettel egyidőben, 1914. június 28-án felállították a Sajtó-hadiszállást (Kriegspressequartier - KPQ), amely a közös haderő főparancsnoksága egyik alosztályaként müködött, és közvetlenül a Vezérkar főnökének alárendeltségébe tartozott. Már 1909-ben elkészült a tervezet egy ilyen szervezet létrehozására. Kidolgozták a Sajtó-hadiszállás szervezetét, müködési rendjét és tevékenysége alapelveit a bel- és külföldi hírek ellenőrzésére vonatkozóan. Ez a szerv látta el a sajtószolgálati feladatokat az uralkodó Főhadsegédi Hivatalánál is. ${ }^{12}$

A Sajtó-hadiszállás parancsnoka Maximilian von Hoen ezredes (majd vezérőrnagy) volt, őt 1917 márciusában Wilhelm Eisner-Bubna vk. ezredes váltotta fel. A szervezet létszáma 1914 végén 400 fő körül mozgott, 1918 nyarára azonban elérte a 880 főt. Kezdetben csak a parancsnokság, a haditudósító csoport és a térparancsnokság adminisztrációs és gazdasági hivatala volt feltöltve, de még 1914-ben megszervezték a művészeti csoportot is. 1917-ben már 12 különböző részleg tartozott a Sajtóhadiszállás alá, melyek a tömegtájékoztatás minden területétét felölelték. A Sajtóhadiszállás kezdetben az orosz front mögött müködött, Duklán, majd ősszel az orosz előretörés miatt Poprád, illetve Zsolna térségébe, végül Teschen körzetébe vonták vissza. A központi elhelyezés hiánya azonban egyre jobban nehezítette a hatékony működést, ráadásul 1915 nyarán megnyílt az olasz front is. A müvészeti csoportot 1916 augusztusától Bécsbe helyezték át, majd 1917-től az egész Sajtóhadiszállás a birodalmi fóvárosba került. A személyzet a fronttól távol végezte a munkáját, ami a hadvezetés számára megkönnyítette, hogy csak kellően megszürt információkat juttassanak el hozzájuk. ${ }^{13}$

A Sajtó-hadiszállás részlegei: 1. parancsnokság, 2. haditudósító csoport, 3. művészeti csoport, 4. belföldi csoport, 5. cenzúra részleg, 6. külföldi csoport, 7. propaganda csoport és ellenséges propaganda-elhárítás, 8. sajtó- és frontpropaganda csoport, 9. fényképrészleg, 10. filmrészleg, 11. „I” (Olaszország) részleg, 12. térparancsnokság. A katonai szolgálatra behívott újságírók jelentős része, 1915-től már minden szerződésben álló újságíró a Sajtóhadiszállás állományába került.

\footnotetext{
${ }^{11}$ Gorda 2012. 48., M. Kondor 1975. 75-82.

${ }^{12}$ Balla 2005. 141.; Molnár 1918. 218.

${ }^{13}$ Cornwall 1992. 52-54.; Stemlerné 2009. 119-120.
} 
Számos ismert személyiség dolgozott a haditudósító csoport keretében, köztük magyar részről Molnár Ferenc és Szép Ernő (Az Est), Herczeg Géza (Pester Lloyd), Jászi Oszkár (Világ), Pogány József (Népszava). A nagyobb lapok általában külön kérvényezték, hogy egy-egy behívás alá eső munkatársukat haditudósítónak osszák be. A csoport létszáma a háború időszakában 60-80 fő körül mozgott. ${ }^{14}$

A haditudósítók általában tiszti zubbonyt és legénységi sapkát viseltek, bal karjukon $K P Q$ vagy Presse feliratú karszalaggal. Az egyes lapok által „delegált” önkéntesek civil ruhát és hasonló karszalagot hordtak. Ök is katonai fegyelem hatálya alá tartoztak, de a laptól továbbra is kapták a fizetésüket. A haditudósítók, különösen a háború első szakaszában nem jutottak ki a tüzvonalba. Feladatuk a főparancsnokságtól kapott hírek szerkesztése, kommentálása volt. Az információs nyersanyagot a föparancsnokság sajtóreferense által összeállított és a Vezérkar által jóváhagyott napi kommünikék képezték. 1915-től a haditudósítók már eljuthattak a front mögötti területekre, az utánpótlási zónába, a magasabb parancsnokságok, segélyhelyek közelébe, és ütközet után bejárhatták az elfoglalt csatateret, de az első vonalba továbbra sem engedték ki őket. A harci eseményekről csak a résztvevők beszámolóiból értesültek. Csak 1916-tól vált lehetővé, hogy egyes haditudósítók nyugalmasabb periódusban meglátogassák az első vonalban lévő csapatokat. Az ott készített sajtóanyagokat első körben a helyileg illetékes katonai parancsnokságok cenzúrázták. ${ }^{15}$

A mûvészeti csoportban részben besorozott, részben önként jelentkező művészek dolgoztak, 1916 augusztusában mintegy 150 fő, köztük 56 magyar (Mednyánszky László, Pór Bertalan, Rippl-Rónai József, Kisfaludi-Strobl Zsigmond). Az elvárás velük szemben havi egy kiállításra is alkalmas alkotás elkészítése volt. Müveikből először 1916 januárjában rendeztek reprezentatív bemutatót Budapesten, a Nemzeti Szalonban, ahol 52 müvész 802 alkotása szerepelt. A képzőművészek képeslapokat, könyv- és lapillusztrációkat, exlibriseket, színes litográfiákat, bélyeg formátumú zárjegyeket, emléklapokat, érmeket, plaketteket, különböző katonai emléktárgyakat, illetve a háború mellett mozgósító vagy hadikölcsönkötvény jegyzésére buzdító plakátokat is készítettek. Részt vettek ünnepségek megtervezésében, emlékmüvek felállításában, haditemetők kialakításában. A művészeti csoportnak nemcsak képző- és iparművész tagjai voltak. Egy kisebb létszámú zenei részleg is tartozott hozzá, amely feladata hazafias zeneművek, katonai indulók komponálása, rendezvények zenei kíséretének összeállítása volt. Ebben a részlegben szolgált Bartók Béla és Kodály Zoltán is. ${ }^{16}$

A belföldi csoport hazai sajtószemlét állított össze, felügyelte a tábori könyvtárakat, a belföldi filmforgalmazást. 1917 áprilisában külön színházi alcsoportot állítottak fel, amely a frontszínházak müködését koordinálta. 1918-ban már 18 társulat járta a harctereket. A külföldi csoport feladata a külföldi sajtó és egyéb kiadványok figyelése, szemlézése volt. Kivonatokat készítettek a szövetséges, a semleges és az ellenséges országok tömegtájékoztatásának a Monarchiát érintő megnyilatkozásairól. A cenzúra részleg a front és a hátország közötti kommunikáció, a frontról hazaküldött, illetve a hátországból a frontra érkező postai küldemények ellenőrzését végezte. A világháború időszakában az összes hadszínteret tekintve mintegy 260 milliárd postai küldemény

\footnotetext{
${ }^{14}$ BALla 2005. 145-147.

${ }^{15}$ Gorda 2012. 49.; STEMLERNÉ 2009. 120-122.

${ }^{16}$ BALla 2005. 144-145.
} 
fordult meg a front és a hátország között. Ebből a Monarchia 20 milliárddal részesedett. A front és a hátország közötti üzenetváltás szigorú ellenőrzéséhez sok ezer cenzorra volt szükség. Ezt a feladatot általában frontszolgálatra nem alkalmas, iskolázottabb katonák látták el. Munkájukat a Sajtó-hadiszállás központi cenzorai irányították és ellenőrizték. A propaganda csoport feladata a Monarchia katonai erejének és erényeinek bemutatása, illetve háborús célok jogosságának alátámasztása volt. Az antant hatékony propagandájának elhiteltelenítésére 1916-ban külön részleg alakult. A sajtócsoport hatáskörébe tartoztak a tábori lapok és hadifogoly kiadványok. A csoporton belül 1918 februárjában frontpropaganda részleget szerveztek, amely a katonák körében mutatkozó kiábrándultság ellensúlyozására hazafias célú oktatást, felvilágosítást végzett. ${ }^{17}$

A fényképrészleg 1918 tavaszáig mintegy 80000 regisztrált felvételt készített és bocsátott a tájékoztatási szervek rendelkezésére. A vizualitás szerepének felértékelődését tapasztalva, 1915 nyarától minden hadsereg- és önálló hadtest-parancsnoksághoz kirendeltek egy-egy hadifényképészt. Mivel a lapokban egyre nagyobb mennyiségben jelentek meg fronton készült amatőr fényképek, és több újság külön fotópályázatot írt ki a minél érdekesebb felvételek beküldésére, a katonai vezetés is nagyobb hangsúlyt helyezett arra, hogy a Sajtó-hadiszállás fényképészeinek munkái is minél szélesebb körben ott legyenek a lapokban. A fénykép expresszív hatást gyakorolt, leegyszerűsítette, ugyanakkor erőteljesebbé és gyorsan befogadhatóvá tette az üzenetet, és társadalmi háttértől, műveltségtől függetlenül komoly befolyást gyakorolt a szemlélőre. A háború borzalmait közvetlenül bemutató felvételek, különösen 1917-től kezdve csak elvétve kerültek a nyilvánosság elé. Még a halál bemutatása is csak hősi pátosszal történhetett. A hadi sikereket sem az ellenfél halottaival illusztrálták, hanem mosolygó hadifoglyokat mutattak, akik örültek, hogy számukra véget ért a harc. A bécsi Hadilevéltár keretében felállított filmkészítő részleget 1917 májusában szintén a Sajtó-hadiszállás alárendeltségébe helyezték. Ez a részleg irányította a háborús és propagandafilmek készítését, valamint heti filmhíradókat, dokumentumfilmeket is forgatott. ${ }^{18}$

Az Monarchiában, a többi nagyhatalomhoz hasonlóan központilag szervezték a háborús propagandát, ez a tevékenység azonban sokkal szerényebb keretek között folyt, mint Németországban vagy Nagy-Britanniában. Ennek részben anyagi okai voltak, de szerepet játszott benne az is, hogy a sajtónak kezdetben kisebb hatást tulajdonítottak, mint a nyugati államokban. A központilag irányított propaganda egy ideig eredményesen ellensúlyozta a háborúval szembeni fenntartásokat és az ellenséges bomlasztó törekvéseket. A háborús hírek elsődleges forrása a Vezérkar által kibocsátott napi helyzetjelentés volt, melyet a Vezérkar főnökének helyettese Franz Höfer vezérőrnagy szignált. Ezek a „höferek”, ahogy azokat sajtókörökben nevezték, képezték a közölhető hadi hírek alapját. A napi jelentésekben közölt tények, a nyilvánvaló propagandaszándék ellenére alapvetően hitelesek voltak. A manipuláció inkább abban jelentkezett, amit elhallgattak, amit kihagytak a jelentésekből. ${ }^{19}$

Osztrák-Magyar Hadiértesitő címen 1917-ben megjelent egy központi kőnyomatos, amely a háborús sajtó egyik fő hírforrásának számított. A lap, a nyers hírek mellett már szerkesztett írásokat is közölt a hadműveletek alakulásáról, a hadigazdaságról, a hadifogolyügyekről.

\footnotetext{
${ }^{17}$ BiHARI 2014. 229.; BALla 2005. 142-145.

${ }^{18}$ LANDGRAF 2015. 132-133., 143-144.; GoRDA 2012. 60-61.

${ }^{19}$ BALla 2005. 149.
} 
A hátországi média számára a Sajtó-hadiszállás újságírói készítették ezeket a feldolgozott anyagokat. A Hadiértesitő cikkeit az MTI továbbította a hazai lapoknak. A Sajtó-hadiszállás megbízottai rendszeresen tájékoztatták a HFB sajtóalbizottságát, hogy milyen információk kerülhetnek nyilvánosságra, és milyen témákat kell kerülni a lapoknak. Az információkat a HFB a polgári sajtóellenőrző szerveknek is továbbította. ${ }^{20}$

Az állóháború kialakulása nyomán a katonák hírigényének kielégítésére hosszabb-rövidebb életű tábori lapok jelentek meg, melyek száma a háború végére elérte a százat. Voltak köztük a Sajtó-hadiszállás által szerkesztett központi kiadványok, az újságok többségét azonban az egyes alakulatok adták ki. Ezek döntően a helyi eseményekkel foglalkoztak, illetve hasznos információkat, egyéni élménybeszámolókat, verseket, novellákat, humoros cikkeket, rajzokat közöltek. Az egyik legismertebb tábori lap a przemyœli erődben kiadott Tábori Újság volt, amely 141 lapszámot ért meg. Az erőd eleste előtti napokban 5200 példányban jelent meg. ${ }^{21}$

\section{MÉDIAHÁBORÚ: CENZÚRA ÉS PROPAGANDA}

A tömegtájékoztatás minden területére kiterjedő cenzúra a háború szerves kísérőjelensége volt. A kormányok nemcsak az érzékeny katonai információkat akarták kiszürni a médiából, vagy a küzdelem célját, jogosságát megkérdőjelező hangokat próbálták elhallgattatni, hanem a hátország gazdasági, társadalmi problémáinak tárgyalását is korlátozták. Nagy-Britanniában már 1914 augusztusában felállították a háborús cenzúrát irányító Sajtó Hivatalt, melyet a belügyminiszter felügyelt. A nyugati államokban a háború kezdetén sokkal átfogóbb és szigorúbb sajtócenzúra müködött, mint Magyarországon. Ennek oka az volt, hogy a sajtó Nyugaton már meghatározó közvélemény és közhangulat alakító tényezőnek számított, és a háborúval kapcsolatos nézetek formálásában is nagyobb szerepet tulajdonítottak neki. A kelet-európai államokban, a korlátozott jogokkal és a kevesebb véleménynyilvánítási lehetőséggel rendelkező, tekintélyelvhez szoktatott lakosság befolyásolására számos más kormányzati eszköz is rendelkezésre állt, így a sajtót nem tekintették meghatározó tényezőnek. ${ }^{22}$

Franciaországban, 1914. szeptember 19-én, a fronton kialakult katasztrofális helyzetre való tekintettel megszigorították a sajtócenzúrát. Attól féltek, hogy a korábbi magabiztos nyilatkozatok után a lakosság nem viselne el még egy, az 1870-1871-es háborúhoz hasonló vereséget. Betiltották az olyan írásokat, amelyek kritizálták a kormány intézkedéseit vagy a katonai vezetés lépéseit, vagy amelyek a harcok beszüntetése, a béke mielőbbi megteremtése mellett emeltek szót. Az újságok csak katonai sikerekről írhattak, az elesettek és sebesültek nagy számát elhallgatták. A veszteségek azonban a későbbi hónapokban még tovább nőttek, az év végére elérték az 510000 főt, amit már nem lehetett eltitkolni a lakosság elől. A sebesültek tömegeinek hazaszállításával a hátország egyre több közvetlen információt kapott a fronton zajló eseményekről. A francia hadvezetés titkolózása visszaütött, amikor szeptemberre közismertté vált, hogy a németek mélyen betörtek az országba, és már a kormány kénytelen elmenekülni Párizsból, hogy biztonságos távolságból szervezhesse a háború folytatását. ${ }^{23}$

\footnotetext{
${ }^{20}$ GoRDA 2012. 50-53.

${ }^{21}$ GoRDA 2012. 66-67.

${ }^{22}$ Bujdosó 2015. 76.; Hastings 2014. 555-556.

${ }^{23}$ HART 2013. 74-76.; KeEGAN 2014. 200.
} 
1914 nyarán az első nagy német sikerek idején Párizsban elterjedt, hogy 250000 orosz katonát indítottak a nyugati államok megsegítésére. A minden alapot nélkülöző hír 1916-ig visszatérően többször is felbukkant a lapokban. A francia és brit újságok esetenként le nem zajlott ütközetekről, valótlan katonai sikerekről adtak hírt, vagy hamis katonaleveleket közöltek, melyek bizakodó hangulatot és kitünő harci szellemet tükröztek. Az, hogy a szigorú cenzúra ellenére ilyen írások megjelentek, és hetekig lekötötték az olvasókat, jól jelezte, hogy a kormányok sem zárkóztak el a civil lakosság megtévesztésétől, a hírek manipulálásától. ${ }^{24}$

Nagy-Britannia, az általános védkötelesség hiánya miatt a háború elején döntően önkéntes erőkkel vette fel a harcot. Mivel Németországnak London üzent hadat, a brit kormánynak a kezdeményezés ódiumát is viselnie kellett. Az első harcok megrázóan súlyos veszteségei után attól tartottak, hogy a rossz hírek kiszámíthatatlan következményekkel járhatnak a lakosság magatartására nézve. Ezért a háború kezdeti időszakában a britek is szigorúan elzárták az információkat a hátország elől. A brit sajtó arculata 1915 folyamán megváltozott. A veszteségekről, a fronton tapasztalható nehézségekről továbbra is csak korlátozottan lehetett írni, a háborús viszonyokról általában azonban már reálisabb képet festettek. A konfliktus elhúzódásáról, a lakosságot sújtó problémákról már nyíltabban beszéltek, mint korábban. A cenzúra mellett a hazafias propaganda erősítése mind nagyobb hangsúlyt kapott. 1918 februárjában Tájékoztatásügyi Minisztériumot állítottak fel, és külön hivatalt hoztak létre az ellenséges országokkal szembeni propaganda irányítására. ${ }^{25}$

A háborús propaganda szempontjából nagy jelentősége volt, hogy Londonnak sikerült a befolyása alá vonni az amerikai közvéleményt. A brit haditengerészet már a háború kezdetén elvágta a kontinensről Amerikába vivő tenger alatti kommunikációs kábeleket. Ezzel igen körülményessé és lassúvá vált a német hírek eljuttatása a semleges Egyesült Államokba, miközben a brit híranyag elárasztotta az USA lakosságát. Az angol hírközlő szervek nagy figyelmet fordítottak az amerikai újságírók, szerkesztőségek tendenciózus tájékoztatására. Az amerikai sajtó nagy része kritika nélkül vette át a Londonból érkező híreket, így a háborús események, illetve a Központi Hatalmak szerepének értékelése tekintetében az amerikai média a brit propaganda anyagát, érvelését, minősítéseit követte. ${ }^{26}$

Oroszországban már a háború előtt szigorú szabályok korlátozták a sajtó működését. A szarajevói merénylet után, de még a Monarchia hadüzenete előtt rendeletet adtak ki a katonai cenzúra bevezetéséről. A háború kirobbanásakor a belügyminiszter hazaárulás terhe mellett megtiltotta, hogy a lapok a kormány hivatalos tájékoztató anyagaiban szereplő híradásokon túl egyéb katonai kérdéseket is tárgyaljanak. A frontra küldött vagy onnan érkező minden levelet cenzúráztak, a lakossági üzeneteket a katonai körzetparancsnokságok, a katonák írásait az egyes seregtesteknél működő cenzorok. 1915 augusztusában nagymértékben kiterjesztették a korlátozást, a katonai mellett 29 további kérdéskört vontak be a kötelező cenzúra keretébe (a külpolitika alakulása, a gazdaság állapota, a társadalmi helyzet, a közélet viszonyai). ${ }^{27}$

\footnotetext{
${ }^{24}$ Ponsonby 1928. 64-66.

${ }^{25}$ Hastings 2014. 264-265., 392-393., SANDERs-Taylor 1982. 231-232.; CoRnWall 2000. 6-7.

${ }^{26}$ LAVine-WechSler 1940. 8., 18-20.

${ }^{27}$ Davidian 2003. 426-427.
} 
Németországban, elsősorban a közvetlen katonai vagy katonapolitikai kérdések tárgyalását tiltották meg a lapoknak. Az újságokban nem jelenhettek meg kritikus hangú kommentárok a kormány külpolitikájáról, a háború indokoltságáról, a hadicélokról, a katonai veszteségekről. A várt gyors győzelem elmaradása miatt 1914 októberében központi cenzúrahivatalt állítottak fel. Ettől kezdve szélesedett a lapokból kitiltott témák köre, és szigorodott a cikkek hangvételének ellenőrzése. A cenzúra kemény fellépését az is magyarázta, hogy a Monarchia és Szerbia konfliktusát formálisan a német hadüzenet szélesítette egész Európát érintő háborúvá. A német kormány semmiképp sem kívánta a lakosság elé tárni, hogy a végzetes döntés milyen súlyos következményekkel járt. A sikerekről szóló híreket viszont fontos mozgósító tényezőnek tekintették. A seregtestek mellett 1916-ra már külön sajtóelőadó tiszt müködött, aki részben a katonai cenzúrát, részben a propagandatevékenységet irányította. ${ }^{28}$

A háború kirobbanásakor az Osztrák-Magyar Monarchiában is általános sajtócenzúra lépett életbe, ez azonban kezdetben csak korlátozottan müködött, nem érvényesült olyan szigorú következetességgel, mint Németországban vagy az antant hatalmaknál. A lapok nem írhattak a katonai nehézségekről és a veszteségek mértékéről. A hadifogolytáborokban uralkodó rossz körülmények bemutatása helyett csak pozitív képet festhettek az ottani viszonyokról. Ez a hamis beállítás nemcsak azért volt fontos, hogy ne érhesse jogos kritika a hadifogoly ügyek kezelését, hanem azért is, hogy kontrasztként lesújtó ítéletet lehessen mondani az antant fogolytáborokban uralkodó helyzetről. A katonai problémák elhallgatása mellett tilos volt közölni háborúellenes véleményeket, a társadalmi feszültségekkel foglalkozó anyagokat, vagy olyan soviniszta hangvételü írást, amely éles reakciót válhatott ki a nemzeti kisebbségek körében. Ezt annál is fontosabbnak tekintették, mert a nemzetiségi származású katonák között érzékelhető volt a szerbekkel kapcsolatos szimpátia, egyes nemzetiségi vidékeken, például a cseh területeken pedig háborúellenes demonstrációkra került sor a polgári lakosság részéről. ${ }^{29}$

A Szerbia elleni hadjárat megindulása után néhány héttel a Monarchia támadása kudarcba fulladt és a csapatok kénytelenek voltak visszavonulni. A sajtó viszont igyekezett légből kapott győzelmi hírekkel megőrizni a hátország lelkesedését. A bécsi lapok nagy sikerekről, 30 szerb zászlóalj szétveréséről írtak, majd dicsérték a jól szervezett visszavonulást, ami nyilvánvaló logikai ellentmondást tükrözött. Hamarosan közismertté vált, hogy az osztrák-magyar csapatok nem értek el komolyabb eredményt, viszont súlyos veszteséget szenvedtek. A hadvezetés igyekezett bagatellizálni a kudarc méreteit. A Szerbia elleni fellépésről egyre inkább, mint jelentéktelen büntetőhadjáratról beszéltek, ami részben máris elérte a célját, mert megfélemlítette a belgrádi kormányt. Ezzel a szerb front mellékhadszíntérré vált a médiában, az ottani események eltörpültek az orosz fenyegetéshez és a galíciai harcokhoz képest. ${ }^{30}$

A háború kezdetén, a magyarországi cenzúra még egységes koncepció nélkül, gyakran ötletszerüen müködött. A sajtó ellenőrzését gyakorló három hatóság között esetenként komoly véleménykülönbségek és hatásköri viták mutatkoztak. A kormány inkább csak általános utasításokat fogalmazott meg, hogy a lapok milyen témákat kerüljenek, és milyen kérdésekről írhatnak bővebben. Ennek nyomán a magyarországi sajtóellenőrzés egy ideig enyhébb volt,

\footnotetext{
${ }^{28}$ Hastings 2014. 556.; Krause 2014. 84-87.

${ }^{29}$ Cornwall 1992. 52-54.; Gorda 2012. 79.; WaWro 2003. 404-405.

${ }^{30}$ Hastings 2014. 226-227.
} 
mint az ausztriai cenzúra. Tisza ellenezte a hadvezetőség azon törekvését, hogy minden újság esetében előzetes bemutatási kötelezettséget vezessenek be. A háború első évében a katonai kérdéseket nem számítva a magyar sajtónak még viszonylag széles mozgástere volt, a lapok szabadon tárgyalhattak számos aktuális problémát. ${ }^{31}$

Az előzetes cenzúra csak bizonyos témákra és csak egyes lapokra (például a Népszavára) vonatkozott. Az újságokkal szemben elvárás volt, hogy a címoldalukon csak pozitív háborús híreket vagy lelkesítő írásokat közöljenek. A nehézségekről szóló cikkek csak a belső oldalakon kaphattak helyet, komolyabb kudarcokról, nagyobb veszteségekről azonban nem lehetett írni. Egyes lapok mégis beszéltek ezekről, de a cenzúra fellépésének elkerülése érdekében, sajátos megoldással, cáfolat formájában. Gyakran előfordult, főként vidéken, hogy egy újság a címlapján derülátó hadi hírekkel jelent meg, a belső oldalakon azonban saját tudósítói vagy hazatért katonák beszámolói alapján, ezeknek ellentmondó információkat közölt. Az ilyen esetek ellen kezdetben a sajtóellenőrzés nem lépett fel túlzott szigorral. ${ }^{32}$

A háború kiszélesedése nagymértékben növelte az érdeklődést a hírek iránt. 1915 végére a lapok példányszáma jelentősen megemelkedett. Az Est egyes időszakokban elérte a 400000 példányt, és a Népszava is napi két kiadásban jelent meg. A fokozódó nehézségek, a növekvő veszteségek, a beígért győzelem elmaradása ekkorra már erősen rontotta a közhangulatot. A közvélemény feletti kontroll megőrzése érdekében a kormány a cenzúra szigorúbb alkalmazására törekedett. Szaporodtak azok a témák, melyeket száműztek az újságokból. Korlátozták az ellátási nehézségekről, illetve a társadalmi megmozdulásokról szóló hírek megjelenését is. Az ellenzéki lapok az aktuális kérdések felvetésekor általában kihasználták, hogy a parlamenti képviselők felszólalásait változtatás nélkül közölhette a sajtó, csak a kommentárokat ellenőrizte a cenzúra. ${ }^{33}$

A hadvezetés rendkívül érzékenyen reagált a háborús tevékenységet érintő sajtókritikára. A katonai körök által kifogásolt cikkeket közlő lapok szerkesztőit a kormányfő bizalmas értesítésben emlékeztette a hadviselés érdekeire, felhívta figyelmüket a kerülendő témákra, illetve a megfelelő hangnem alkalmazására. A közös Hadügyminisztérium radikális fellépést sürgetett a Népszava, és néhány más baloldali újságok ellen. A feszült társadalmi helyzetben azonban a magyar kormány kerülni akarta a lapok betiltása nyomán várható felháborodást, ezért inkább burkolt lépésekkel akadályozta az ellenzéki sajtó müködését. A Népszava és néhány laptársa terjesztését hivatalosan ugyan nem korlátozták, a hadseregtől azonban igyekeztek távol tartani. A helyi parancsnokok saját hatáskörükben megtiltották, hogy a katonák a laktanyákban ilyen újságokat olvassanak. A hadmüveleti területre postán kiküldött példányokat a hadvezetés utasítására rendszeresen megsemmisítették. ${ }^{34}$

A magyarországi sajtóellenőrzésben 1915 végén fordulat következett be. A cenzúra egyre szigorúbban ellenőrizte az újságokat, és egyre több szöveget törölt a bemutatópéldányokból. A kihúzott sorok helyén üres felület, „fehér ablak” maradt, ami az olvasók számára is jelezte a cenzúra tevékenységét. A címek jól megmutatták, hogy milyen témát kellett kihúzni a lapból. A kormány igyekezett titkolni a cenzúra létezését. A HFB felhívta a szerkesztők figyelmét,

\footnotetext{
${ }^{31}$ BiHARI 2008. 172-173.

${ }^{32}$ VARga 1996. 155.; Gorda 2012. 61-62.

${ }^{33}$ MuCSI 1984. 197-198.

${ }^{34}$ MuCSI 1984. 198.
} 
hogy a törölt mondatok helyét ne hagyják üresen, töltsék ki más szöveggel. A szaporodó fehér foltok miatt 1916-ban elrendelték, hogy a cenzorok ne egyes mondatokat, hanem egész bekezdéseket vagy cikkeket töröljenek, amelyek helyére be lehet illeszteni egy másik írást. Az indoklás szerint, az üres felületeknek ,riasztó hatásuk” van az olvasókra. Ekkorra már a növekvő papírhiány is nehezítette a sajtó tevékenységét. A fokozott háborús felhasználás és a központi hatalmakat sújtó blokád miatt a tartalékok elfogytak. 1916-ban Újságpapír Központot állítottak fel, amely kvóta szerint utalta ki az egyes lapoknak a felhasználható papírmennyiséget. A kormány ezen keresztül is kontrollálta a sajtót, csökkentette az újságok terjedelmét, szabályozta az egyes rovatok, illetve a hirdetések arányát. ${ }^{35}$

I. Károly császár trónra lépése után Ausztriában változás következett be a sajtóirányítás területén. A hosszabb szünet után ismét összehívott osztrák parlamentben éles felszólalásokra került sor a HFB cenzúra tevékenysége ellen. Ennek hatására átszervezték az intézményt, 1917 októberétől kivonták a haderő közvetlen irányítása alól. Magyarországon viszont Tisza lemondása után az új kormány a társadalmi elégedetlenség fokozódását a cenzúra szigorítása révén próbálta megakadályozni. Tovább bővült a sajtóban nem tárgyalható témák köre. A lapokból kitiltották a nemzetiségi feszültségekről, a munkáskövetelésekről, sztrájkokról, a béketapogatózásokról szóló híreket. Különösen veszélyesnek ítélte a kormány a háborúellenes megnyilvánulások bemutatását. ${ }^{36}$

A fronton harcoló katonák „nyugalmának” biztosítása érdekében a Sajtó-hadiszállás megtiltotta a társadalmi problémákról, a hátországi nehézségekről nyíltabban beszélő lapok katonák közötti terjesztését. A szociáldemokrata és polgári radikális sajtó mellett már egyes mérsékelt konzervatív újságok frontra való kiküldését is felfüggesztették, illetve bevezették velük szemben is az előzetes bemutatási kötelezettséget. A társadalmi problémák általános felvetését nem akadályozták, konkrét katonai vagy kormányzati lépések kritizálását, illetve az elégedetlenség fokozódását jelző megnyilvánulások tárgyalását viszont nem engedték. A tilalmaknak azonban egyre nehezebb volt érvényt szerezni. Bár a katonai vezetés a korábbinál még szigorúbb korlátozásokat sürgetett a sajtóval szemben, az ellátási nehézségek, a súlyos veszteségek, a szociális gondok miatti megmozdulások, a háborúellenes megnyilatkozások, vagy az oroszországi forradalmi események egyre inkább nyilvánosságot kaptak. A semleges országok sajtója továbbra is hozzáférhető volt. A rendszeres médiafogyasztó közönség tehát viszonylag széleskörüen tudott tájékozódni. ${ }^{37}$

A világháború során a propaganda szerepe felértékelődött. Sokan úgy látták, hogy a média meghatározó befolyást képes gyakorolni a társadalmi folyamatokra, sőt akár a fegyveres harc alakulására is. A háború civilizációk harcaként jelent meg a tömegkommunikációban. A propaganda, mindkét oldalon egy sajátos normatív értelmezést kínált a saját közvélemény számára, és a konkrét háborús célok jogosságának igazolásán túl a morális igazságot is a saját oldalnak vindikálta. Nagy-Britannia és Franciaország a modernitás, a szabadság bajnokaként lépett fel, és harcot hirdetett, az elnyomott népek védelmében, az egész Európát veszélyeztető levitézlett abszolutizmusok militáns törekvéseinek megfékezésére. Oroszország, a balkáni szláv népek felszabadítója szerepét öltötte magára, hangoztatva, hogy a szláv testvériség, a kulturális összetartozás jegyében, erkölcsi parancsra siet a fenyegetett Szerbia segítségére. ${ }^{38}$

\footnotetext{
${ }^{35}$ M. Kondor 1975. 80-81; Gorda 2012. 80; MuCSI 1984. 196-197.

${ }^{36}$ Cornwall 1992. 59-60.; Healy 2004. 25.; Bihari 2008. 173-174.

${ }^{37}$ Deist 1991. 159-161.; Bihari 2000. 174.; Cornwall 1992. 61-63.

${ }^{38}$ Schmitt 1937. 235-236.; LAmbert 2012. 200-202.; PalÉologue 1982. 76.; PaÁl 2010. 152-154.
} 
Németország viszont az elüzletiesedő, dekadens Nyugattal szemben Európa megújulásáért hirdetett harcot. A német sajtó a briteket haszonleső árulóknak nevezte, akik gazdasági érdekeik miatt rászabadítják a kontinensre az orosz barbárságot. A Monarchia, állítása szerint csak a Délkelet-Európa békéjét veszélyeztető, titkos társaságok irányítása alá került szerb politika megrendszabályozására fogott fegyvert, az orosz támadás után pedig európai életformája megőrzése érdekében kellett folytatnia a harcot. ${ }^{39}$ Saját propaganda szerint tehát mindkét fél védekező háborút vívott, amit a másik oldal kényszerített rá, és amelynek tétje nemcsak saját szabadsága, kultúrája védelme, hanem egész Európa békéjének, stabilitásának biztosítása. A fegyveres harcot ezért a korábbi évszázadok dinasztikus, területszerző vagy hatalmi fölényt biztosító háborúival szemben most nem lehetett valamilyen megegyezés útján lezárni. Az ellenséget mindkét fél a megtestesült gonoszként, a barbárság képviselőjeként mutatták be, melyet nem elég kapitulációra kényszeríteni, mert további fenyegetést jelent. Addig kell ellene folytatni a küzdelmet, amíg teljesen szét nem zúzzák, meg nem törik. ${ }^{40}$

A propaganda nemcsak a saját erények, értékek felmutatására törekedett, hanem az ellenség lejáratására is. Mivel korábban az európai népek között nem volt éles szembenállás, a háborús propagandára várt a feladat, hogy a harcoló felek közvéleményét végletesen egymás ellen hangolja és ezzel a végsőkig tartó erőfeszítésre ösztönözze az állandó életveszéllyel szembenéző katonákat és a háborús nehézségekkel küszködő hátországot. ${ }^{41}$ Mindkét oldal igyekezett minden pozitív tulajdonságától megfosztani, dehumanizálni az ellenfelet, ezzel is megerősítve, hogy békés megegyezésről nem lehet szó. A szélsőséges beállítás félresöpörte a másik fél igazságát, értelmetlenné tette a vele szembeni méltányos elbánást, így az ellenség elpusztítása nem csak elfogadhatóvá, hanem egyenesen kötelességgé vált. A saját erőszak jogosságának igazolása érdekében mindkét fél messze eltúlozta a másik brutalitását. Mindez morális felmentést adott a béke idején érvényesülő erkölcsi és jogi normákkal össze nem egyeztethető magatartás felelőssége alól, a kormányoknak és az átlagembereknek egyaránt. ${ }^{42}$

A háború kezdettől totális jelleget öltött, melyben nemcsak a szembenálló haderők, hanem az ellenfél hátországa, gazdasága és kulturális javai is célpontnak számítottak. Felmerült ugyan, hogy a harcoló feleknek tartózkodniuk kellene a másik oldal kulturális értékeinek szándékos elpusztításától és a lakosság elleni erőszakos fellépéstől, de a résztvevőkre egyre súlyosabb terheket rakó, az ellentéteket a végletekig élező elhúzódó háború körülményei között csak a siker számított, morális önkorlátozást senki sem vállalt. Ezt példázta többek között a hátország ellen kibontakozó légi háború. A központi hatalmak gépei az antant országok polgári célpontjaira mintegy 15000 bombát dobtak, amely 2953 halott és 5925 sebesült áldozatot követelt, az antant repülők pedig 18000 bombával támadták Németország és a Monarchia hátországát, 1131 halott és 2721 sebesült áldozatot okozva. ${ }^{43}$

\footnotetext{
${ }^{39}$ Herwig 1998. 78-80; SiPOS 2011. 49.

${ }^{40}$ Schmitt 2002. 235.; BenOist 2014. 98-99.

${ }^{41}$ SiPos 2011. 48.; Pollmann 2015. 51.; BeCKer 2010. 243.

${ }^{42}$ Ponsonby 1928. 13-14.; PAÁl 2010. 146.; Wehler 2004. 32.

${ }^{43}$ HunKe 1935. 13-14.; Morrison 1937. 117-118.; Crane 1993. 14-15.
} 
A brit és francia lapok széles körben terjesztették a német hadsereg Belgiumban elkövetett rémtetteit. A háború kezdetén német csapatok a polgári lakossággal szemben igen durva fellépést tanúsítottak. A belga ellenállás, a tapasztalatlan katonák között kirobbanó orvlövész-pánik, illetve a háborús elszántság fokozására központilag is táplált gyülöletkampány drasztikus tettekre ragadtatta a németeket. A gerillatámadások megtorlásaként (vagy arra hivatkozva) számos túszszedés, kivégzés fordult elő, falvakat égettek fel, nem volt ritka a nők elleni erőszak vagy a lakosság kényszermunkára való elhurcolása sem. A belgiumi és észak-franciaországi területeken 130 komolyabb incidens során mintegy 6000 polgári személyt öltek meg. Az antant sajtó igyekezett még inkább eltúlozni az atrocitásokat. A szuronyra tűzött csecsemőkről, megcsonkított anyákról, legyilkolt apácákról, illetve a hadifoglyok tömeges kivégzéséről szóló híradások azonban nem feleltek meg a valóságnak. ${ }^{44}$

Szerbiában is nagyarányú gerillatevékenység bontakozott ki a bevonuló osztrák-magyar haderővel szemben. A katonai vezetés erőszakos intézkedésekkel, az elrettentés eszközével próbálta kézben tartani a szerb lakosságot, amivel azonban inkább az ellenkező hatást érte el. Tisza az értelmetlen erőszakoskodás, kivégzések megszüntetése érdekében közvetlen az uralkodóhoz fordult, és elérte, hogy az igazságszolgáltatás a megszálló katonai szervektől a polgári hatóságokhoz kerüljön át. A német vagy osztrák-magyar csapatok által elkövetett kegyetlenségek hírével megtelt a nyugati hatalmak médiája által dominált világsajtó. ${ }^{45}$ A kialakult kép azonban egyoldalú volt, mert az antant erők hasonló cselekedeteiről már jóval kevesebben értesültek. Kétségtelen tény, hogy nagyobb mértékü erőszak alkalmazására a polgári lakossággal szemben brit vagy francia részről nem került sor, mert az antant erők a háború elején nem foglaltak el jelentősebb német vagy osztrák-magyar területeket. Civilek elleni erőszak, illetve a hadifoglyokkal való durva bánásmód azonban az antant oldalán is előfordult. Az orosz erők részéről lengyel területen tömeges atrocitások is történtek. ${ }^{46}$

A központi hatalmak propagandája ugyancsak eltúlzott vádakat fogalmazott meg az antant államokkal szemben. A német média felnagyította a belga és a francia ellenállás méreteit és embertelen módszerekkel vádolta a gerillákat. A német és osztrák-magyar sajtó széles körben terjesztette az orosz csapatok civil lakosság elleni brutális magatartásáról, vagy az antant haderők hadifoglyokkal szembeni könyörtelen bánásmódjáról szóló híreket. Nagy teret kapott a központi hatalmak tömegtájékoztatásában a francia és brit kötelékben harcoló színes bőrü gyarmati csapatok kérdése is. Az afrikai katonákat gyakran primitív, erkölcsöt nem ismerő vadembernek mutatták be, és egyenesen háborús bünnek nevezték, hogy az antant ilyen erőket szabadít rá a civilizált európai népekre. ${ }^{47}$

A magyar közvélemény háborúval kapcsolatos felfogása különbözött az osztrák és német, vagy a nyugati államok lakosságának nézeteitől. Az elfogadott, támogatott háborús cél nem a másik fél teljes legyőzése volt, hanem csak Szerbia megfékezése. A többi fronton való harcot csak kényszernek, az orosz, illetve az olasz támadás következményének tekintették. Ez azt jelentette,

\footnotetext{
${ }^{44}$ Bujdosó 2015. 77-78.; Bihari 2014. 184-185.; Wolz 2008. 354-355.; PonsonBy 1928. 68-70.

${ }^{45}$ Hastings 2014. 220-221.; Hajdú-Pollmann 2014. 152-153.

${ }^{46}$ Ferguson 2009. 443-445.; LANDGRAF 2015. 145.

${ }^{47}$ Marquis 1978. 487.; Demm 1993. 176.
} 
hogy a közvélemény szemében a Monarchia 1915-re elérte kitűzött célját, legyőzte Szerbiát. Ettől kezdve a háború folytatása már csak egy megfelelő béke elérését szolgálta. Az antanttal szembeni szélsőséges hangnem a magyar médiát kevésbé jellemezte. Bár az újságok a szerbeket gyakran banditáknak, összeesküvőknek nevezték, ezt elsősorban a belgrádi politikai körökre vonatkoztatták, nem az egész népre. E tekintetben a kormány magatartását is bizonyos visszafogottság jellemezte. Miközben propagálta Szerbia megbüntetését, a legyőzött ország beolvasztásának lehetőségét elvetette. ${ }^{48}$

A fronton zajló események mellett a harcoló felek között átfogó médiaháború bontakozott ki. A kormányok politikai propagandaanyagokkal (az osztrák-magyar vörös könyv, a német fehér, a brit kék, a francia sárga, az olasz zöld, a belga szürke az orosz narancssárga és a szerb kék könyv) próbálták igazolni a világ és saját lakosságuk előtt a hadba lépés jogosságát és elkerülhetetlenségét. Igyekeztek csatasorba állítani a szellemi élet kiválóságait, tudósokat, művészeket, hogy vegyenek részt a hazafias propagandában és az ellenfél démonizálásában. ${ }^{49}$ Németországban 93 ismert személyiség (köztük Max Weber és Albert Einstein) kiáltványt intézett a „,civilizált világhoz”, melyben a hadba lépést az európai kultúra védelmét szolgáló döntésnek nevezték, és elutasították a német haderő erőszakos magatartásáról szóló nyugati vádakat. Franciaországban Henri Bergson, Anatole France Camille Saint-Saëns és mások nemcsak a porosz imperializmust és az önkényuralmi rendszert ítélték el, hanem azt állították, hogy az erőszak a germán kultúra szerves része. 1914 októberében 54 ismert brit író a New York Times hasábjain állt ki az antant által folytatott háború jogossága mellett. ${ }^{50}$

A kulturális „mozgósítás” részeként a lapok megteltek hazafias irodalmi betétekkel, a színházak a nemzeti összetartozás erősítését szolgáló darabokat játszottak. Az emberek környezetében, hétköznapi tárgyain, az üzleti kirakatoktól a használati eszközök díszítéséig, a bélyegektől a képeslapokig a nemzeti identitás szimbólumai és a háborús kötelességteljesítés jelképei jelentek meg. A köztereken szobrok, emlékművek emlékeztettek a katonák hősi küzdelmére. Igyekeztek háborúra hangolni a gyerekeket is, militarizált játékokkal vagy a fémgyüjtésre való mozgósítással. A francia kormány a katolikus egyházzal közösen átfogó programot indított a gyerekek bevonására. Központilag kiadott útmutatók segítették, hogy az iskolai tananyag, a vizsgakérdések, a tanórán kívüli foglalkozások a háborús célok mellett lelkesítsenek. Az iskolásokat bevonták a frontra küldendő szeretetcsomagok összeállításába. A gyerekek leveleket írtak a frontkatonáknak, hogy kitartásra ösztönözzék őket. Mindez azt a megközelítést erősítette, hogy a háborút nem aktuális politikai vagy gazdasági rivalizálás okozta, hanem a küzdelem egy életforma, egy értékrend megvédéséért folyik. ${ }^{51}$

A propaganda rendkívül hatékony eszközének bizonyultak a plakátok. Az olcsón és nagy tömegben előállítható, folyamatosan szem előtt lévő, minden társadalmi réteget megszólító plakát, jelentős szerepet kapott a közvélemény alakításában. A magyar lakosság elsősorban a hadikölcsön

\footnotetext{
${ }^{48}$ BIHARI 2008. 175.

${ }^{49}$ TomKa 2015. 16; Pollmann 2015. 52.

${ }^{50}$ Hastings 2014. 557.; Mulligan 2010. 4.

${ }^{51}$ Horne 1997. 41.; Bihari 2014, 157-158.; Audoin-Rouzean 2003. 767-770.
} 
jegyzésére buzdító kiadványokkal találkozhatott. Ezek 1915 végéig a nemzeti összefogást, a győzelembe vetett hitet igyekeztek erősíteni. A későbbiekben a háborús diadal helyét a katonákkal való szolidaritás és a béke kivívása vette át a plakátok üzeneteiben. ${ }^{52}$

A háború időszakában jelentősen megnőtt az érdeklődés a mozgókép iránt. A mozi nemcsak a szórakoztatásban kapott szerepet, hanem a híradó és dokumentumfilmek révén a tömegtájékoztatás és propaganda területén is. A britek a háború kezdetétől kiaknázták a mozgóképben rejlő propagandalehetőségeket. Nagy-Britanniában a mozilátogatók száma az 1914-es heti 7 millió föről, 1917-re 21 millióra emelkedett. A legnagyobb nézettséget 1916-ban a somme-i csatáról készült dokumentumfilm érte el. A mozi Franciaországban is fokozatosan megelőzött minden más tömegszórakozási formát. A híres párizsi mulatók, a műsor részeként filmbetéteket vetítettek. A francia katonai vezetés is felismerte a mozgókép jelentőségét. A hadsereg megrendelésére a háború alatt több mint 600 film készült. A központi hatalmaknál viszont alulértékelték a film propagandaszerepét. A német kormány csak 1917-től fordult nagyobb figyelemmel a mozi felé. Erich Ludendorff tábornok javaslatára létrehoztak egy állami ellenőrzés alatt álló központi filmvállalatot (UFA). A mozi iránt a Monarchiában is fokozott érdeklödés jelentkezett. Magyarországon 1914-ben 18 film készült, 1918-ban 102 film. A mozgókép propagandacélokra való felhasználását azonban nem tartották fontosnak. Miközben Nyugaton már tucatszám gyártották a hazafias szellemủ háborús filmeket, a Monarchiában csak a híradóban rejlő lehetőségeket próbálták kiaknázni, illetve a mozikat arra kötelezték, hogy a vetítések előtt népszerúsítsék a hadikölcsönöket. ${ }^{53}$

Az I. világháború minden korábbi európai konfliktusnál nagyobb megrázkódtatást jelentett a kontinens lakossága számára. A hadba lépő államok közel 65 millió embert mozgósítottak, amelynek közel 15\%-a (9,5 millió fö) elesett, 32\%-a (21 millió fó) pedig megsebesült a harcok során. A korábbi fegyveres konfliktusokkal szemben már nem vált el élesen egymástól a front és hátország, a behívott katona és a civil polgár. Ha különböző mértékben és más-más módon, de a háború hatásai mindenkit közvetlenül érintettek. A kormányoknak magyarázni, indokolni kellett a világégés, a katonai veszteségek és a polgári lakosság szenvedésének okát, és rá kellett mutatni a felelősökre. ${ }^{54} \mathrm{~A}$ háború, mint az embereket leginkább foglalkoztató téma mindenhol jelen volt. A katonai, politikai és gazdasági téren zajló összecsapás mellett a szellemi szférában, a tudomány, a művészetek, a média területén is totális küzdelem zajlott. ${ }^{55} \mathrm{~A}$ szembenálló felek mindent elkövettek, hogy a tömegkommunikáció eszközeivel is erősítsék pozícióikat, mozgósítsák saját országukat és kivívják a semleges államok szimpátiáját, illetve jelentős energiát áldoztak arra, hogy lejárassák, meggyűlöltessék az ellenfelet, semlegesítve a másik fél médiatevékenységét. A tömegtájékoztatás és a háborús propaganda központilag irányított, iparszerủ tevékenysége komoly hatást gyakorolt mind a fronton harcoló katonák, mind a hátországi társadalom gondolkodására, magatartására.

\footnotetext{
${ }^{52}$ SzABÓ 2011. 140.

${ }^{53}$ ReEves 2003. 781-782.; MARWICK 1970. 115-116.; BiHARI 2008. 168-170.

${ }^{54}$ WinTer 2012. 160-162.; SCHMitT 2002. 236.

${ }^{55}$ KISS 2015. 55.
} 


\section{FELHASZNÁLT IRODALOM}

Audoin-Rouzean, Stephane (2003): French Children as Target for Propaganda. In: Cecil, Hugh Liddle, Peter H. (eds.) Facing Armageddon. The First World War Experienced. Barnsley, Pen \& Sword. 767-779.

BALla TiBOR (2005): Az osztrák-magyar sajtóhadiszállás szervezete és tevékenysége az első világháborúban. Hadtörténelmi Közlemények 118. évf. 1-2. sz. 141-151.

Benoist, Alain de (2014): Hogyan veszítette el a háborút Európa? In: MARKó GyörGY SCHMidT MÁRIA (szerk.): Európai testvérháború 1914-1918. Budapest, Közép- és Kelet-Európai Történelem és Társadalom Kutatásáért Közalapítvány. 97-104.

Becker, Anette (2010): Faith, Ideologies, and the 'Cultures of War'. In: Horne, John (ed.): A Companion to World War I. Chichester, Wiley and Blackwell. 234-247.

BIHARI PÉTER (2008): Lövészárkok a hátországban. Középosztály, zsidókérdés, antiszemitizmus az elsö világháború Magyarországán. Budapest, Napvilág.

Bihari Péter (2014): 1914. A nagy háború száz éve. Budapest, Kalligram.

Bujdosó István (2015): Nagy-Britannia propagandatevékenysége az első világháborúban. Együtt 14. évf. 3. sz. 74-98.

CORnwall, MARK (1992): News, Rumour and the Control of Information in Austria-Hungary, 1914-1918. History vol. 77. no. 249. 50-64.

CORnWAll, MARK (2000): The Undermining of Austria-Hungary: The Battle for Hearts and Minds. New York, Palgrave Macmillan.

Crane, Conrad C. (1993): Bombs, Cities and Civilians. American Airpower Strategy in World War II. Lawrence, University Press of Kansas.

Davidian, Irina (2003): The Russian Soldier's Morale from the Evidence of Tsarist Military Censorship. In: Cecil, Hugh - Liddle, Peter H. (ed.): Facing Armageddon. The First World War Experienced. Barnsley, Pen \& Sword. 425-433.

Deist, Wilhelm (1991): Zensur und Propaganda in Deutschland Wärend des Ersten Weltkrieges. In: Deist, Wilhelm (hrsg.): Militär, Staat und Gesellschaft. München, Oldenbourg.

Demm, Eberhard (1993): Propaganda and Caricature in the First World War. Journal of Contemporary History vol. 28. no. 1. 163-192.

Ferguson, Niall (2009): The Pity of War. 1914-1918. New York, Penguin. 443-445.

GALÁNTAi JÓzSEF (2001): Magyarország az első világháborúban. Budapest, Korona.

GORDA Éva (2012): A magyar haditudósitás az első és a második világháborúban. Budapest, NKE.

Hajdú Tibor - Pollmann Ferenc (2014): A régi Magyarország utolsó háborúja. Budapest, Osiris.

Hart, Peter (2013): The Great War. London, Profile Books.

Hastings, Max (2014): 1914 Európa lángba borul. Budapest, Gabo. 
Healy, Maureen (2004): Vienna and the Fall of the Habsburg Empire. Cambridge, Cambridge Unuversity Press.

Herwig, Holger H. (1998): The First World War: Germany and Austria-Hungay, 1914-1918. London, Arnold.

Horne, John (1997): State, Society and Mobilization in Europe During the First World War. Cambridge, Cambridge University Press.

HunKe, HeInRICH (1935): Luftgefahr und Luftschutz. Berlin, E. S. Mittler \& Sohn.

KeEgan, John (2014): Az elsö világháború. Budapest, Akadémiai.

KISS GÁBOR FERENC (2015): Erőviszonyok az első világháború előestéjén, In KISS GÁBOR FERENC VINCZE GÁBOR (szerk.): „,...kedves bajtársim kössétek be sebem”. A Nagy Háború emlékezete. Ópusztaszer - Szeged, Ópusztaszeri Nemzeti Történeti Emlékpark - Belvedere Meridionale. 49-73. KÓKAY GYÖRGY - BuZINKAY GÉZA - MurÁNYI GÁBOR (1999): A magyar sajtó története. Budapest, Sajtóház.

Krause, Wolfgang (2014): Der Erste Weltkrieg. Darmstadt, Wissenschaftliche Buch Gesellschaft. Lambert, Nicholas A. (2012): Planning Armageddon. London, Harvard University Press.

LANDGRAF ILDIKÓ (2015): Háború és béke képei a Vasárnapi Újságban az I. világháború alatt. In: Klestenitz Tibor - Sz. NAGy GÁBOR (szerk.): Médiatörténeti tanulmányok 2014. 127-156.

Lavine, Harold - WechSler, James (1940): War Propaganda and the United States. New Haven, Yale University Press.

LiPTÁK DOROTTYA (2002) Újságok és újságolvasók Ferenc József korában. Budapest, L'Harmattan.

M. KONDOR VIKTÓRIA (1975): Adalékok az első világháború alatti sajtó és cenzúra történetéhez. Magyar Könyvszemle 91. évf. 1. sz. 75-82.

Marquis, Alice Goldfarb (1978): Words as Weapons: Propaganda in Britain and Germany during the First World War. Journal of Contemporary History vol. 13. no. 3. 467-498.

Marwick, Arthur (1970): Britain in the Century of Total War. London, Pelican.

MolnÁr FERENC (1918): Egy haditudósitó emlékei. Budapest, Franklin.

Morison, Frank (1937): War on Great Cities. London, Faber \& Faber.

MuCSI FERENC (1984): Sajtócenzúra Magyarországon az első világháború idején. Történelmi Szemle 27. évf. 1-2. sz. 192-202.

Mulligan, William (2010): The Origins of the First World War. Cambridge, Cambridge University Press.

PaÁl Gergely (2010): Háború - gyülölettel. Bolyai Szemle 19. évf. 4. sz. 143-160.

PalÉOlogue, Maurice (1982): A cárok Oroszországa az első világháború alatt. Franciaország nagykövetének naplójából. Budapest, Európa. 
Pollmann FERENC (2015): A hadviselés átalakulása az első világháborúban: haditechnika, stratégia és propaganda. In: ToMKA BÉLA (szerk.): Az elsö világháború következményei Magyarországon. Budapest, Országgyülés Hivatala. 45-54.

Ponsonby, Arthur (1928): Falsehood in War Time. London, George Allen \& Unwin. (1942. London, Bradford \& Dickens).

Reeves, Nicholas (2003): Through the Eye of the Camera. In: Cecil, Hugh - Liddle, Peter H. (eds.): Facing Armageddon. The First World War Experienced. Barnsley, Pen \& Sword. 780-798.

ROMSICS IGNÁC (2010): Háborús mindennapok - alulnézetből. In: RoMSICS IGNÁC (szerk.): Magyarország az első világháborúban. Budapest, Kossuth - Hadtörténeti Intézet és Múzeum. 119-133.

SAnders, Michael - TAylor, PhiliP M. (1982): British Propaganda during the First World War, 1914-18. The Macmillan Press Ltd. London.

SCHMitT, CARL (1937): Totális ellenség, totális háború, totális állam. In: Schmitt, Carl: A politika fogalma. Válogatott politika- és államelméleti tanulmányok. Budapest, Osiris - Pallas Stúdió Attraktor.

Sipos BALÁzs (2011): Sajtó és hatalom a Horthy-korszakban. Budapest, Argumentum.

STEMLERnÉ BAlogh Ilona (2009): Történelem és fotográfia. Budapest, Osiris - Magyar Nemzeti Múzeum.

TOMKA BÉLA (2015): Az első világháború, mint történeti korszakhatár. In: ToMKA BÉLA (szerk.): Az elsö világháború következményei Magyarországon. Budapest, Országgyülés Hivatala. 7-24.

VARGA LAJos (1996): Garami Ernő. Budapest, Napvilág.

VocelKA, KARL (2014): Az Osztrák-Magyar Monarchia az első világháborúban: háborús remények és a bukás okai. In: MARKÓ GYÖRGY - SCHMIDT MÁRIA (szerk.): Európai testvérháború 1914-1918. Budapest, Közép- és Kelet-Európai Történelem és Társadalom Kutatásáért Közalapítvány. 141-151.

Wawro, Geoffry (2003): Morale in the Austro-Hungarian Army. In: Cecil, Hugh - Liddle, Peter H. (eds.): Facing Armageddon. The First World War Experienced. Barnsley, Pen \& Sword. 399-412.

Wehler, Hans-Urlich (2004): Der zweite Dreißigjährige Krieg. Burgdorff, Stephan Wiegrefe, Klaus (Hsrg.): Der Erste Weltkrieg: Die Ur-Katastrophe des 20. Jahrhunderts. München, Deutsche Verlags-Anstalt.

Winter, JAY (2012): Demography. John Horne (ed.): A Companion to World War I. Chichester, John Wiley and Sons. 248-262.

Wolz, Nicolas (2008): Das lange Warten. Kriegserfahrungen deutscher und britischer Seeoffiziere. 1914 bis 1918. Paderborn, Schöningh. 